\title{
HISTORIES OF THE PRESENT: GIOVANNI ARRIGHI \& THE LONG DUREE OF GEOHISTORICAL CAPITALISM
}

\author{
Thomas E. Reifer \\ Department of Sociology \\ University of San Diego \\ reifer@sandiego.edu
}

One of the more telling features of the present conjuncture is the scarcity of analysis able to squarely place today's global turbulence and the current crises in geohistorical perspective. In terms of the longue duree of capitalism since its late medieval and early modern origins right up to the present, arguably no intellectual has developed a more formidable analysis of the present crisis than Giovanni Arrighi. Arrighi of course, along with Immanuel Wallerstein (1974, 1980, 1989) and the late Terence Hopkins, was one of the originators and foremost proponents of the world-systems perspective on European domination, global capitalism, global income inequalities and "development" (see Arrighi, Hopkins \& Wallerstein, 1989). The world-systems perspective itself - challenging as it did the dominance of post-World War II modernization theory - came out the movements of the 1960s and brought together fruitful synthesis of Marxism, Third World radicalism, and critical currents in social science, from the work of the French Annales school to that of the German historical school (see Goldfrank 2000).

Wallerstein and Hopkins developed the world-systems perspective at Columbia University and eventually migrated to Binghamton University in the 1970s. Arrighi joined the faculty in the late 1970s playing a role in the graduate program and the Fernand Braudel Center and participated in various collective research working groups.

The range and scope of Arrighi's work - from analysis of settler capitalism in Southern Africa to his analysis of Adam Smith in Beijing is truly an astonishing achievement. Ravi Sundaram, director of the Centre for the Study of Developing Societies in Delhi, noted at a conference honoring and critically discussing Arrighi's work that Giovanni exhibited a generosity of spirit towards his intellectual interlocutors that had few equals. ${ }^{1}$ Arrighi thrived on spirited debates within the framework of mutual solidarity, surely a necessary part of the renewal of progressive forces around the globe.

The conference in Madrid was intended to be a sort of reunion and an occasion to discuss the current crisis and Giovanni's work in historical perspective. Despite his absence (due to illness) the conference was a great success, with spirited discussions and debates maintaining a growing energy for the entire five days, often during marathon sessions.

Born in Milan in 1937, his family's anti-fascist attitudes shaped Giovanni's political trajectory. Originally trained in neoclassical economics in Italy and then involved in a series of different business enterprises, Arrighi eventually migrated to then Rhodesia (Zimbabwe) in the early 1960s. William Martin (2005, p. 381) noted that "World-systems analysis, like the capitalist

\footnotetext{
${ }^{1}$ Papers from the conference, which was sponsored by Spain's Museo Nacional Centro de Arte Reina Sofia (see http://madrid2009arrighi.blogspot.com/), are expected to be published in an edited volume in the next few years.
} 
world-economy, has deep African roots.” Arrighi's (2009) migration to Africa was in his own words, "a true intellectual rebirth," one where he "began my long march from neo-classical economics to comparative-historical sociology." Here, along with others he developed a pioneering politico-economic analysis focused on the contradictions engendered by the proletarianization and dispossession of the Southern African peasantry.

In Rhodesia Giovanni met Bhasker Vashee. They were even cell mates, jailed for their anti-colonial activities. By 1966 Giovanni had moved to Dar es Salaam, at the time when Tanzania was a home for national liberation movements from all over Africa. Here, Arrighi's colleagues included a wide range of radical scholar activists, including John Saul, Walter Rodney, Immanuel Wallerstein, and a host of others.

Later Giovanni returned to Italy to teach and was involved in movements stressing the autonomy of the working-class - autonomia - helping to found Gruppo Gramsci. By the late 1970s Arrighi had turned his sights towards the analysis of imperialism, completing the landmark work The Geometry of Imperialism (1983). It was around this time that Giovanni began to reconceptualize this work as a bridge towards what would become arguably his most significant book, The Long Twentieth Century. This manuscript is widely considered the single most important book ever published on the longue duree of world capitalism to date, not the mention perhaps the most fundamental work for understanding the current crisis of global capitalism. Arrighi argued that capitalism evolved over a series of long centuries, within which recurrent combinations of governmental and business organizations have led successive systemic cycles of accumulation (SCA). These cycles have been characterized by material expansions of the capitalist world-system; when these expansions reach their limits, capital moves into the realm of high finance, where interstate competition for mobile capital provides some of greatest opportunities for financial expansions.

The obverse side of these financial expansions has been the reciprocal stimulus of military industrialization and haute finance as part of the larger restructuring of the world-system that accompanies autumns of SCAs and the hegemonic structures of which they are a part. Financial expansions initially lead to a temporary efflorescence of the declining hegemonic power. Eventually, however, they give way simultaneously to increasing systemic chaos as well as new organizational revolutions in an emerging hegemonic bloc of business and governmental organizations "endowed with ever-more extensive and complex organizational capabilities to control the social and political environment of capital accumulation on a global scale," a process which as Arrighi (1994, pp. 14, 18) noted has a clear "built-in limit."

Unlike Wallerstein, but like Braudel, Arrighi locates the origins of world capitalism not in the territorial states of Europe during the long sixteen century, but instead in the Italian citystates of the $13^{\text {th }}$ and $14^{\text {th }}$ centuries. Arrighi then traces the alliance of Genoese capital and Spanish power that produced the great discoveries, before going on to analyze the changing fortunes of the Dutch, British, and US hegemonies, their respective SCAs and the challenges posed to US power the by the East Asian economic renaissance. In a series of subsequent works that made up what Arrighi called a unplanned trilogy, Chaos \& Governance in the Modern World System and Adam Smith in BeijingI, as well as in a series of articles and updated version of the Long Twentieth Century (forthcoming), Arrighi carried this powerful analysis forward to the present.

Arrighi's unique perspective on large-scale, long-term social change seems eerily prescient in light of recent events. For example, Arrighi \& Silver's (1999, pp. 273-274) 


\section{JOURNAL OF WORLD-SYSTEMS RESEARCH}

proposition, "The global financial expansion of the last twenty years or so is neither a new stage of world capitalism nor the harbinger of a 'coming hegemony of global markets.' Rather, it is the clearest sign that we are in the midst of a hegemonic crisis. As such, the expansion can be expected to be a temporary phenomenon that will end more or less catastrophically...” Today

the financial expansion itself seems to rest on increasingly precarious grounds," resulting in a "backlash" which "announces that the massive redistribution of income and wealth on which the expansion rests has reached, or is about to reach, its limits. And once the redistribution can no longer be sustained economically, socially, and politically, the financial expansion is bound to end. The only question that remains open is this respect is not whether, but how soon and how catastrophically the present global dominance of unregulated financial markets will collapse... But the blindness that led the ruling groups of these states to mistake the "autumn" for a new "spring" of their hegemonic power meant that the end came sooner and more catastrophically than it might otherwise have...A similar blindness is evident today.

So

A more or less imminent fall of the West from the commanding heights of the world capitalist system is possible, even likely...the United States has even greater capabilities than Britain did a century ago to convert its declining hegemony into an exploitative dominion. If the system eventually breaks down, it will be primarily because of U.S. resistance to adjustment and accommodation. And conversely, U.S. adjustment and accommodation to the rising economic power of the East Asian region is an essential condition for a non-catastrophic transition to a new world order (Arrighi \& Silver 1999, pp. 272-288).

In Adam Smith in Beijing, Arrighi returned to many of these issues in light of reemergence of a Chinese-centered East Asia and America's reckless gamble to continue its hegemonic reign with the invasion and occupation of Iraq, home to the second largest reserves of oil in the world. Rather than heralding a new age of US hegemony Arrighi (2007) emphasized instead how the ambitions of the Project for the New American Century, whose members staffed key positions in the Bush White House, ironically has increased the long-term likelihood that we will increasingly be speaking of the US in the $21^{\text {st }}$ century Asian age.

Adam Smith in Beijing, like its predecessors, is a difficult and ambitious book because of the density of the analysis and the scope of its ambitions. Arrighi (2007: xi) notes, the book's purpose "is as much to offer an interpretation of the ongoing shift of the epicenter of the global political economy from North America to East Asia in light of Adam Smith's theory of economic development, as it is to offer an interpretation of The Wealth of Nations in light of that shift." At the same time, the book also tackles a number of other issues, notably the reasons for what Kenneth Pomeranz (2000) has called the "great divergence” between Western Europe, its settler offshoots and East Asia. In the latter part of the book Arrighi traces the growing the bifurcation between US global military power and East Asia's increasing economic power - evidenced in the accumulation of trillions surpluses in Chinese-led East Asia and their investment in US treasury security and other dollar-denominated assets, including sub-prime mortgages. These developments are seen as anomalies which have no real precedent in previous SCA and related hegemonic cycles. 
Arrghi's book takes up an appreciation and critique - albeit in comparative worldhistorical perspective - of what many consider to be the most significant analysis of the present long downturn, by Robert Brenner (1998, 2002, 2006). In many ways this is not surprising, revealing as is it is of Arrighi's method. As a teacher and scholar, Arrighi always instructed his students and colleagues to attack an argument on its strong and not weak points, challenging criticisms by reminding them of their responsibility to come up with better explanations than those they criticized.

It was Brenner's critique of "neo-Smithian Marxism" and associated views on the origins of capitalist development that contrasted most sharply with that of the world-system perspective. In terms of their analysis of the origins of capitalist development, Arrighi and Brenner could not be further apart. The burden of Brenner's critique of Wallerstein's world-system perspective focused on the centrality of class relations and the class struggle in agriculture, to the exclusion of virtually everything else, locating the origins of capitalist development in the English countryside as opposed to in the context of an emerging world-system.

Yet on the question of capitalist agriculture Wallerstein and Brenner, despite their great differences, following in the tradition of the Annales focus on rural history have more in common with each other than with Arrighi's Long Twentieth Century, in which agricultural capitalism plays little to no role in the origins of capitalist development on a world scale. As Walter Goldfrank (2000, p. 162) remarked Wallerstein's focus had much in common with Barrington Moore (1966). In dramatic contrast, Braudel's version of capitalist history, following Oliver Cox (1959), located capitalism on the top level of world-trade and high finance - and only to a lesser extent industry - and that is the position to which Arrighi largely adhered.

In terms of the current crisis, though, Arrighi and Brenner have much more in common, both in terms of the analysis of the long boom and the subsequent long downturn, crisis, and financial expansion. One paradox here though is that Brenner gives an account of the crisis that is quite similar to Arrighi's own neo-Smithian analysis of the end of all material expansions, that increasing competition brings down profits. Thus, both Arrighi and Brenner consider the current crisis not as a financial crisis as such but instead as emblematic of a much deeper crisis of capitalism and capitalist production - exacerbated by government action - dating from the long downturn of the 1970s. Brenner however largely characterizes this as a crisis of over-production, whereas Arrighi's sees it instead as primarily a crisis of over-accumulation. Arrighi, in contrast to Brenner, sees the current long downturn and crisis and the related financial expansion as related to the continuing crisis of US hegemony, akin to the troubles of British hegemony in the late $19^{\text {th }}$ and early $20^{\text {th }}$ century, including to some degree to power of labor. Once again, in contrast, Brenner, he largely discounts the role of the class struggle in the origins of the long downturn, focusing instead almost exclusively on inter-capitalist competition.

Another difference is Brenner's almost exclusive focus both on manufacturing and Japan, Germany, and the US, in contrast to Arrighi's greater emphasis on finance and the financialization of capital - notably the development of offshore money markets - as well as US hegemony and global geopolitics. A decisive turning point here for Arrighi that relates both these realms was the US-led militarized financial expansion of the late 1970s and early 1980s, within which the US competed for mobile capital on the global capital markets by borrowing via the most regressive means possible. This was a crucial shift, as Washington abandoned its earlier tolerance for forms of developmentalism in favor of a counter-revolution in development policy associated with the so-called Washington Consensus. 


\section{JOURNAL OF WORLD-SYSTEMS RESEARCH}

In an interview with David Harvey, Arrighi (2009) reflected on his work. Harvey queried: "The current crisis of the world financial system looks like the most spectacular vindication of your long-standing theoretical predictions that anyone could imagine. Are there any aspects of the crisis that have surprised you?” Arrighi responded that he did miss the details of the bubbles, from the dot com or the housing bubble, to the periodization of the Belle Epoque of US hegemony, which now he sees as really gaining steam under Clinton. "With the bursting of the housing bubble, what we are observing now is, quite clearly, the terminal crisis of US financial centrality and hegemony."

Among the central aspects of Arrighi’s (1994, pp. 4-5; 2009, pp. 90-94) periodization of global capitalism is the fundamental convergence with Braudel and Schumpter's emphasis on capitalism's flexibility, non-specialization and capacity for change and adaptation. Herein lies the privileged role of money capital and the system of national debts in restarting capitalism as it accumulates in declining centers and aims to lay claim on future incomes by investing in rising hegemons, from Venice to the US. Equally as important is Arrighi's steadfast related emphasis on geohistory in which he demonstrates how recurrent combinations of geography and history have made and unmade capitalist fortunes.

Among the most important albeit neglected aspects of Arrighi's analysis - and one central to understanding his deployment of Gramsci's concept of hegemony in the context of capitalism as a global system - is that it was the recurrent battles between capitalist and territorialist powers that have always been central to the making and remaking of global capitalism. Here, though seldom noted, Arrighi's capitalist and territorialist powers were to a great extent synonyms for the recurrent battles between naval and later air powers and territorialist powers.

As Arrighi emphasizes, financial expansions and the intensified competition for mobile capital and growing systemic chaos which as a rule characterize hegemonic transitions each ended in the remaking of the global system on new and enlarged social foundations under a rising hegemonic power, or at least the collapse of the Continental challenger. The last episode of this was revealed most recently in the dramatic fall of the Soviet empire and Soviet Union itself, in a battle won on the global capital markets as much as on any battlefield, as Arrighi many times underscored. This schema revealed capitalism's eclecticism and flexibility and the evolutionary nature as it grew to global scope.

Another critical aspect of Arrighi's (1990, 1991, 2002) work is the analysis of geoeconomic regions and global income inequalities. Here Arrighi always aimed to take into account: a) the pre-colonial heritage; b) the impact of colonialism; and c) post-colonial developments, within the framework of comparative world-historical analysis. The thrust of Arrighi's most recent work was to combine his long term comparative analysis of sub-Saharan Africa with his more recent work on East Asia, as well as to analyze development in other regions, from what he called the organic core - including Western Europe - and parts of Italy.

The present day crisis of capitalism on a world scale would seem an especially fortuitous time to revisit the important debates on the nature of capitalist development, its origins, future trajectories, possible demise and realistic world-historic alternatives. A key question is what type of alternative system(s) might better approximate humanity's hopes for a more democratic, egalitarian, peaceful, and socially just world order(s). Arrighi (1998) noted that as helpful as nondebates may have been in the past for protecting emerging research agendas against their premature demise, "eventually they become counterproductive for the full realization of their 
potentialities. I feel that world-systems analysis has long reached this stage and that it can only benefit from a vigorous discussion of issues that should have been debated long ago but never were.”

Perry Anderson has some revealing passages about the question of capitalist origins. After reviewing Brenner's argument on the centrality of agricultural capitalism in England - to the exclusion of virtually everything else - in the origins of capitalist development, including towns and overseas commerce, Anderson admits:

For all the power of this case, there were always difficulties with its overall context. The idea of capitalism in one country, taken literally, is only a bit more plausible than that of socialism...Historically, it makes better sense to view the emergence of capitalism like this: as a value-added process gaining in complexity as it moved along a chain of interrelated sites. In this story, the role of cities was always central. English landowners could have never started their conversion to commercial agriculture without the market for wool in Flemish towns (2007, Ch.

12, p. 251).

No one to my knowledge has yet noted the convergence between Brenner and Wallerstein - in dramatic contrast to the work of Braudel and Arrighi - on the centrality of agricultural capitalism in the emergence of capitalism. Of course, the differences here are even greater than the affinities: capitalism develops in the countryside of the English state for Brenner and in the context of the emerging world-system for Wallerstein. Wallerstein (1974) sketched the interrelations between agricultural capitalism and Braudel's top level of world trade and finance. Yet to date no one has sufficiently explored how these dynamic forms of agricultural capitalism might be related to the growth of capitalism at the top level of world trade and finance (Braudel 1981, 1982, 1984; Arrighi 1994). In many ways this is not surprising since the thrust of Braudel's and Arrighi's work has been discount the potential importance of agriculture in the worldsystemic origins of capitalist development.

Equally as significant is Arrighi's return to his own earlier work on the role of labor supplies. Here Arrighi focuses on the contradictions of capital accumulation by dispossession via full proletarianization revealed in the "Africa of the labor reserves" throughout much of Southern Africa. The combination of white settler colonialism, including in agriculture, mineral wealth, and related labor shortages led to the full dispossession of much of the African peasantry, so as to provide low cost migrant labor for the mines and manufacturing industry. Over time this ended up raising labor costs.

The Southern African experience stands in marked contrast to accumulation without dispossession and associated "rural development and industrialization" throughout much of East Asia. The paradox is that the full proletarianization of the original producers through accumulation with dispossession, although classically associated with the origins of capitalist development, has become one of the biggest barriers to successful capitalist development in Southern Africa and perhaps much of the Global South (Arrighi, Aschoff \& Scully 2009). Arrighi uses differing trajectories of accumulation with or without dispossession and associated policies of racial exclusion to examine the radical divergence in development experiences in East Asia and Southern Africa. Specific policy changes in Southern Africa are offered to address these challenges, most especially the need for land distribution to the landless and increases in education and social welfare that can benefit the vast majority of Africans. 


\section{JOURNAL OF WORLD-SYSTEMS RESEARCH}

Though it has not been done to date, one can imagine teasing out a series of geohistorical linkages between Marx, Wallerstein's, Braudel's and Arrighi's work on the "top level of worldtrade and high finance" - with the work of Barrington Moore, Brenner, Wallerstein and others on agricultural capitalism, that relates these developments in an original synthesis. The idea would be to demonstrate more fully how capitalist agriculture, urbanization, and what Arrighi calls a "capitalist system of statemaking and warmaking" are all intimately entwined in the worldhistorical origins of capitalist development. Also of interest would be see whether Hart (2002) and Arrighi's work on accumulation with and without dispossession in contemporary Southern Africa and East Asia might also shed some light on the origins of capitalist development trajectories in agriculture analyzed by Brenner and Wallerstein. These debates about past and present are of course intertwined.

As a New Left Review (1977) editorial noted

The famous debate in the 1940s among Marxist historians - Dobb, Sweezy, Hilton, Takahashi and others - on the origins of capitalism stands as one of the most sustained international exchanges on a central theoretical issue to have taken place within historical materialism. The implications of its conflicting accounts of how capitalism emerged, and why it did so in some regions of the world rather than others, were clearly of far more than purely historical interest. They affect assessments of the coordinates of class struggle on a global scale today, interpretations of the bourgeois state and conceptions of the transition from capitalism to socialism. The debate further involved a series of key theoretical problems concerning the nature of historical determination, the relation of economics to politics and the validity of Marx's basis analysis of capitalism.

Much the same could be said for present day debates on these matters in light of new developments and research findings. Arrighi had hoped in recent years to put together a compilation of his most important work on the foundations of global inequality. One can only wonder to what extent Arrighi might have drawn in this endeavor on the important work done on inequalities over the last few years.

In the meantime, there could be no better tribute to Giovanni Arrighi and his quest for a more humane global system than for scholars and activists to return to these central questions as integral parts of our continuing efforts to understand the world and transform it in more peaceful, socially just, and egalitarian directions. Among the most significant losses in the maelstrom of contemporary $21^{\text {st }}$ century life, replete with its sound bite culture and elite intellectuals, is the virtual disappearance of attempts at analyzing the present in the longue duree. Giovanni Arrighi's work - and that of his collaborators - represents a pioneering effort to do exactly this.

\section{REFERENCES}

Anderson, Perry. 2007. Spectrum: From Right to Left in the World of Ideas. New York: Verso. Arrighi, Giovanni. 1983. The Geometry of Imperialism. London: Verso.

. 1991. "World Income Inequalities and the Future of Socialism." New Left Review, \# 189, September/October, pp. 39-68. 
. 1994. The Long Twentieth Century: Money, Power and the Origins of Our Times. New York: Verso ( $2^{\text {nd }}$ updated edition, forthcoming).

. 1998. "Capitalism and the Modern World-System: Rethinking the Non-Debates of the 1970s." Review 11:1:113-129.

. 2002. "The African Crisis: World Systemic \& Regional Aspects,” New Left Review 15, May/June, pp. 1-38.

2007. Adam Smith in Beijing: Lineages of the Twenty-First Century. London: Verso Press.

2009. “The Winding Paths of Capital: Interview by David Harvey," New Left Review 56, March/April 2009, pp. 61-96.

Arrighi, Giovanni, Beverly J. Silver, et al. 1999. Chaos and Governance in the Modern World System. Minnesota: University of Minnesota Press.

Arrighi, Giovanni, Terence K. Hopkins \& Immanuel Wallerstein. 1989. Antisystemic Movement. New York: Verso.

Braudel, Fernand. 1981, 1982, 1984. Civilization and Capitalism, 15th-18th Century, Volumes 1III. New York: Harper \& Row.

Brenner, Robert. 1998. “The Economics of Global Turbulence.” New Left Review 299, May/June 1998.

. The Boom \& the Bubble: The US in the World-Economy. New York: Verso.

. 2006. The Economics of Global Turbulence. New York: Verso, $2^{\text {nd }}$ edition, forthcoming, 2009.

Goldfrank, Walter L. 2000. "Paradigm Regained? The Rules of Wallerstein's World-System Method.” Journal of World-Systems Research 6:2(Summer/Fall):150-195. http://jwsr.ucr.edu/archive/vol6/number2/pdf/jwsr-v6n2-goldfrank.pdf

Hart, Gillian. 2002. Disabling Globalization: Places of Power in Post-Apartheid South Africa. Berkeley: University of California Press.

Martin, William. 2005. "Africa \& World-Systems Analysis. Pp. 381-402 in Writing African History, edited by John Edward Philips. Rochester.University of Rochester Press.

New Left Review. 1977. “Editorial Introduction,” July-August, Number 104, p. 1.

Pomeranz, Kenneth. 2000. The Great Divergence: China, Europe, \& the Making of the Modern World Economy. Princeton: Princeton University Press.

Wallerstein, Immanuel. 1974. The Modern World-System I: Capitalist Agriculture and the Origins of the European World-Economy in the Sixteenth Century. Orlando: Academic Press.

. 1980. The Modern World-System II: Mercantilism and the Consolidation of the European World-Economy, 1600-1750. New York: Academic Press.

1989. The Modern World-System III: The Second Era of Great Expansion of the Capitalist World-Economy, 1730s-1840s. New York: Academic Press. 